\title{
Non-nutritive Sucking Habits of Preschool Children in Daejeon
}

\author{
Seunghyo Bak', Nanyoung Lee', Sangho Lee', Hyeran Jeong² \\ ${ }^{1}$ Department of Pediatric Dentistry, College of Dentistry, Chosun University \\ ${ }^{2}$ Department of Dental Hygiene, Dong-A Injae University
}

\begin{abstract}
The purpose of this study was to determine the prevalence of non-nutritive sucking in preschool children in Daejeon. This study assessed the relationship between contributing factors influencing the prevalence of nonnutritive sucking. Also, the effects of non-nutritive sucking on the primary dentition were investigated.

The study included 841 children 18 65 months of age that visited a pediatric private dental clinic for oral examination. Both children and their guardians were surveyed.

It was found that $32.8 \%$ of children exhibited non-nutritive sucking, and $37.7 \%$ of females displayed this behavior. The number of females showing this behavior was significantly greater than that of males. The prevalence decreased significantly with the breast-feeding period, and there was no association with either birth rank or maternal occupation.
\end{abstract}

Finger sucking (62.6\%) was more prevalent and of longer duration than pacifier sucking (37.4\%). Malocclusion of the primary dentition was associated with the duration of this behavior.

Key words : Non-nutritive sucking habit, Finger sucking, Pacifier sucking, Anterior open bite, Large overjet

\section{I. 서 론}

빨기는 신생아의 기본적인 반사반응으로 영유아에서 영양적 인 욕구뿐 아니라 심리적인 욕구도 충족하기 위한 것으로 정상 적인 발달과정의 어린이는 빨기에 대한 고유한 동기가 있다 ${ }^{1)}$. 빨기는 영양섭취를 위한 영양성 빨기와 손가락이나 인공젖꼭지 등을 빠는 행위인 비수유성 빨기로 구분할 수 있다. 비수유성 빨기 습관은 이유기 단계로 이행시 심리적인 욕구에 의해 발생 하며, 불안이나 스트레스 상황에서 조절능력을 얻고 접촉과 안 정의 옥구를 만족 시키려는 행위이다2). 정상적인 발달과정의 어 린이도 비수유성 빨기 습관을 할 수 있으며 대개 1 세 전에 나타 나 1 3세 동안 사라진다 ${ }^{3)}$.

구강습관의 발생빈도는 사회문화관습적 영향에 따라 크게 달 라져 지역에 따라서 매우 다양하게 보고되고 있는데 빨기 습관
도 나라와 인종마다 유병률에 차이가 있다. 스웨덴 등 북유럽에 서의 연구는 70 90\%의 아이들이 인공젖꼭지를 사용하며 손 가락빨기는 그보다 더 적다고 하였다.5). 미국에서의 연구는 1 세 때 $30 \%$ 의 어린이가 손가락빨기를 하고, $40 \%$ 의 어린이가 인공젖꼭지를 사용하나 시간이 지나면서 감소되어 4세 때 손가 락빨기는 $10 \%$, 인공젖꼭지는 $5 \%$ 이하에서 나타남을 보고하였 닿. 아시아에서는 비수유성 빨기 습관 빈도가 서구보다는 낮게 보고되는 경향이 있는데 2008년 일본에서 18 개월 592 명의 어 린이를 대상으로 한 연구에서는 $25.5 \%$ 가 손가락빨기를 하고 인공젖꼭지를 $7.6 \%$ 에서 사용한다고 하였고 2005년 연구에서 는 $15.2 \%$ 에서 인공젖꼭지를 사용한다고 하였다 ${ }^{7.8)}$. 또한 홍콩 어린이를 대상으로 한 연구에서는 전체 비수유성 빨기 습관 유 병률은 $35.6 \%$ 이고 그 중 $60 \%$ 가 인공젖꼭지를 사용한다고 하 였다9). 현재까지 국내에서 비수유성 빨기 습관의 유병률을 연구

\footnotetext{
Corresponding author : Nanyoung Lee

Department of Pediatric Dentistry, College of Dentistry, Chosun University, 375 Seosuk-dong, Dong-gu, Gwangju, 501-825, Korea

Tel: +82-62-220-3860 / Fax: +82-62-220-8240 / E-mail: nandent@chosun.ac.kr

Received June 16, 2014 / Revised August 7, 2014 / Accepted August 11, 2014

※ This study was supported by research funds from Chosun University Dental Hospital, 2014.
} 
한 문헌은 찾아보기 어렵다.

비수유성 빨기 습관의 발생에 기여할 수 있는 요인으로는 수 유방법, 성별, 출생순서, 어머니의 직업 등으로 알려져 있다. Telles 등 ${ }^{10}$ 은 모유수유를 오래할수록 인공젖꼭지 사용이 감소 한다고 하였고, Scavone 등1ㄷㄷㅗ 3 6세의 아이들을 대상으로 후향적 연구를 한 결과 모유수유 기간이 길어질수록 손가락빨 기와 인공젖꼭지빨기가 감소하다고 하였다. 성별에 따른 차이 는 주로 여아에서 많은 편이라는 보고와 성별차이는 없다는 보 고가 있달-16). 또한 Ngom 등ㄱㅇㅢ 2008년 연구에서는 수유방 법 및 어머니의 직업이 비수유성 빨기 습관 유병률과 유의한 관 련이 있다고 하였다. Warren 등 ${ }^{18)}$ 은 600 명 어린이를 대상으로 한 장기연구에서 어머니의 나이가 많고 교육수준이 높으며 아 이가 첫째인 경우 빨기 습관을 지속하는 경향이 있다고 하였다. 대부분의 아이들은 만 3 4세에 습관을 멈추지만 일부 어린이 에서는 그 이후까지도 지속하며, 지속되는 비수유성 빨기 습관 이 전치부 개방교합, 수평피개 증가, 2 급 견치관계, 구치부 반 대교합 등의 부정교합과 관련이 있다는 것은 여러 연구를 통해 이미 보고된 바가 있으나 비수유성 빨기 습관이 어느 기간 이상 지속될 경우 부정교합을 유발하는가에 대해서는 여전히 논란이 되고 있다 ${ }^{19)}$.

이 연구의 목적은 실제 우리나라 미취학 어린이의 비수유성 빨기 습관의 유병률을 조사하고 이 유병률에 영향을 미치는 문 화적 요인 및 수유와의 관련성을 평가하며 이런 습관이 유치열 의 교합에 어떤 영향을 주는지 알아보고자 하는 것이다.

\section{II. 연구 재료 및 방법}

\section{1. 연구 대상}

영유아 구강검진을 위해 대전광역시의 소아치과에 내원한 만 18 개월에서 65 개월 사이의 어린이와 그 보호자 900 명을 대상 으로 하였다. 설문에 응답한 900 명의 어린이와 보호자 중 내용 이 부분 누락된 응답자를 제외하고 841 명을 대상으로 분석을 하였다.

\section{2. 연구 방법}

설문지는 두 영역으로 구분하였으며 첫 번째 영역은 설문대 상자의 생년월일, 나이, 성별, 출생 시 상황, 출생 순서, 수유방 법 및 기간, 어머니의 직업, 비수유성 빨기 습관의 여부 등으로 구성되었다. 두 번째 영역은 비수유성 빨기 습관이 있다고 응답 한 경우를 대상으로 습관의 유형, 지속 기간, 빈도 등에 대해 답 하도록 구성하였다. 이후 한 명의 검사자가 모든 어린이의 교합 상태를 검사하였는데, 유치열의 전치부 개방교합, 수평피개 증 가, 견치 교합관계, 구치부 반대교합 유무를 확인하고 기록하였 다. Katz 등이 과 Karjalainen 등 ${ }^{21}$ 의 논문에 따라 전치부 개방 교합은 유전치 간의 교합이 존재하지 않을 때 기록하였고, 수평 피개의 증가는 상악 유전치 설면이 대합되는 하악 유전치 협면
보다 전돌 되어 있을 때 그 양을 기록하고 $3 \mathrm{~mm}$ 이상일 때 증 가된 것으로 간주하였다. 구치부 반대교합은 최소한 한 개의 상 악 유구치가 하악 유구치의 협측교두 보다 설측으로 교합될 때 기록하였다.

\section{1) 설문지 $1:$ 개인적 특성}

아이의 출생 시 상황(미숙아 또는 정상아), 몇 째 아이인지, 수유방법(모유 또는 젖병수유), 어머니의 직업 유무, 손가락이 나 인공젖꼭지를 빠는 습관 유무를 조사하였다.

2) 설문지 2 : 습관의 유형, 지속 기간, 빈도

빠는 습관이 있다고 대답할 경우 주로 빠는 것, 빠는 기간과 정도를 조사하였다.

\section{3) 교합 차트}

전치부의 수직피개와 수평피개의 정도, 견치 교합관계, 구치 부 교합상태를 조사하여 기록하였다.

\section{4) 통계 분석}

설문의 응답과 비수유성 빨기 습관 사이에 통계적 유의성이 있는지 알아보기 위해 SPSS 20 (SPSS INC., Chicago, IL, USA)를 이용하여 Chi - square test, Linear by linear test, Fisher's exact test 통계 분석을 하였으며 유의수준 $95 \%$ ( $p$ $=0.05)$ 에서 검정하였다.

\section{III. 연구 성적}

\section{1. 개인적 특성}

조사대상 어린이들의 연령은 18 개월에서 65 개월로 평균 40.4 개월이었다(Table 1). 성별은 남아가 $53.3 \%$, 여아가 $46.7 \%$ 로 남아가 많았으며 출생 시 상황은 정상아가 $93.1 \%$, 미숙아가 $6.9 \%$ 로 대부분 정상아였다. 출생 순서는 첫째가 $45.7 \%$, 둘째가 $34.8 \%$, 외동이 $13.7 \%$, 셋째 이상이 $5.8 \%$ 로 첫째가 가장 많았다.

모유수유 기간은 6 개월 이하가 $37.8 \%, 6 \sim 12$ 개월이 $23.2 \%, 12 \sim 24$ 개월이 $34.8 \%, 24$ 개월 이상이 $4.0 \%$ 였다. 어

Table 1. Age distribution

\begin{tabular}{ccc}
\hline Age (month) & Number & Percent (\%) \\
\hline $18 \sim 24$ & 170 & 20.2 \\
$25 \sim 36$ & 177 & 21 \\
$37 \sim 48$ & 212 & 25.2 \\
$49 \sim 60$ & 225 & 26.8 \\
$61 \sim 65$ & 57 & 6.8 \\
\hline Total & 841 & 100 \\
\hline & Range : $18 \sim 65$ month & mean $=40.4$ month \\
\hline
\end{tabular}


Table 2. Rates of various associated factors for analysis of non-nutritive sucking

\begin{tabular}{llcr}
\hline & Factor & Number & Percent \\
\hline Gender & Male & 448 & $53.30 \%$ \\
Birth & Female & 393 & $46.70 \%$ \\
& Normal & 782 & $93.00 \%$ \\
Birth rank & Premature & 59 & $7.00 \%$ \\
& only & 115 & $13.70 \%$ \\
& first & 384 & $45.70 \%$ \\
& second & 293 & $34.80 \%$ \\
Breast feeding & more than third & 49 & $5.80 \%$ \\
& $\sim 6$ month & 318 & $37.80 \%$ \\
& 6 12 month & 195 & $23.20 \%$ \\
Bottle feeding & $12 \sim 24$ month & 293 & $34.80 \%$ \\
& $24 \sim$ month & 35 & $4.00 \%$ \\
& not use & 355 & $42.20 \%$ \\
& $\sim 12$ month & 180 & $21.40 \%$ \\
Mother's occupation & 12 24 month & 278 & $33.10 \%$ \\
& Housewife & $28 \sim$ month & $3.30 \%$ \\
& Fultime & 526 & $62.50 \%$ \\
& Parttime & 246 & $5.80 \%$ \\
& Home working & 20 & $29.30 \%$ \\
Total & & 841 & $2.40 \%$ \\
\hline & & & $100 . \%$ \\
\hline
\end{tabular}

머니의 직업은 전업주부가 $62.5 \%$, 전일제근무가 $29.3 \%$, 반일 제근무가 $5.8 \%$, 재택근무가 $2.4 \%$ 였다(Table 2).

\section{2. 비수유성 빨기 습관의 유병률과 기여요인과의 관계(Table 3)}

1) 성별

전체적으로 비수유성 빨기 습관을 한 적이 있다고 응답한 경 우는 276명으로 $32.8 \%$ 였으며 성별비율은 여아 393명 중 146 명 $(37.7 \%)$, 남아 448명 중 130명 $(29.0 \%)$ 으로 여아에서 유 의하게 높았다 $(p<0.05)$.

2) 출생 시 상황

미숙아는 $48.3 \%$, 정상아는 $31.7 \%$ 로 미숙아에서 유의하게 비수유성 빨기 습관 유병률이 높았다 $(p<0.05)$.

3) 출생 순서

출생 순서에 따른 비수유성 빨기 습관 유병률은 유의한 차이 를 보이지 않았다 $(p>0.05)$.

4) 수유 방법 및 기간

시간에 따른 유의성을 검증하기 위하여 Linear by linear test를 시행한 결과 모유수유 기간이 증가함에 따라 비수유성

Table 3. Non-nutritive sucking prevalence and associated factors

\begin{tabular}{|c|c|c|c|c|}
\hline & \multirow{2}{*}{ Factor } & \multicolumn{2}{|c|}{ Number(\%) } & \multirow{2}{*}{$p$-value } \\
\hline & & NNS & None & \\
\hline Overall prevalence & & $276(32.8 \%)$ & $565(67.2 \%)$ & \\
\hline \multirow{2}{*}{ Gender } & Male & $130(29.0 \%)$ & $318(71.0 \%)$ & \multirow{2}{*}{$0.014^{*}$} \\
\hline & Female & $146(37.7 \%)$ & $247(62.3 \%)$ & \\
\hline \multirow{2}{*}{ Birth } & Normal & $248(31.7 \%)$ & $534(68.3 \%)$ & \multirow{2}{*}{$0.005^{*}$} \\
\hline & Premature & $28(48.3 \%)$ & $31(51.7 \%)$ & \\
\hline \multirow{4}{*}{ Birth rank } & Only & $42(36.5 \%)$ & $73(63.5 \%)$ & \multirow{4}{*}{0.188} \\
\hline & Eldest & $134(34.9 \%)$ & $250(65.1 \%)$ & \\
\hline & Second & $89(30.4 \%)$ & $204(69.6 \%)$ & \\
\hline & more than second & $11(22.4 \%)$ & $38(77.6 \%)$ & \\
\hline \multirow{4}{*}{ Breast feeding } & $\sim 6$ month & $153(48.1 \%)$ & $165(51.9 \%)$ & \multirow{4}{*}{$0.000^{*}$} \\
\hline & $6 \sim 12$ month & $59(30.3 \%)$ & $136(69.7 \%)$ & \\
\hline & 12 24 month & $58(19.8 \%)$ & $235(80.2 \%)$ & \\
\hline & $24 \sim$ month & $6(17.1 \%)$ & $29(82.9 \%)$ & \\
\hline \multirow{4}{*}{ Bottle feeding } & Not use & $71(19.9 \%)$ & $286(80.1 \%)$ & \multirow{4}{*}{$0.000^{*}$} \\
\hline & $\sim 12$ month & $74(40.8 \%)$ & $107(59.1 \%)$ & \\
\hline & 12 24 month & $122(43.4 \%)$ & $159(56.6 \%)$ & \\
\hline & $24 \sim$ month & $9(40.9 \%)$ & $13(59.1 \%)$ & \\
\hline \multirow{2}{*}{ Use of bottle } & Not use & $71(19.9 \%)$ & $286(80.1 \%)$ & \multirow{2}{*}{$0.000^{*}$} \\
\hline & Use & $205(42.4 \%)$ & $279(57.6 \%)$ & \\
\hline \multirow{4}{*}{ Mother's occupation } & Housewife & $164(31.2 \%)$ & $362(68.8 \%)$ & \multirow{4}{*}{0.682} \\
\hline & Fulltime working & $90(36.9 \%)$ & $156(63.1 \%)$ & \\
\hline & Halftime working & $16(32.3 \%)$ & $33(67.7 \%)$ & \\
\hline & Home working & $6(30.0 \%$ & $14(70.0 \%)$ & \\
\hline Total & & $276 / 841$ & $565 / 841$ & \\
\hline
\end{tabular}

Chi-square test, significant at $p<0.05$ level $(*)$ 


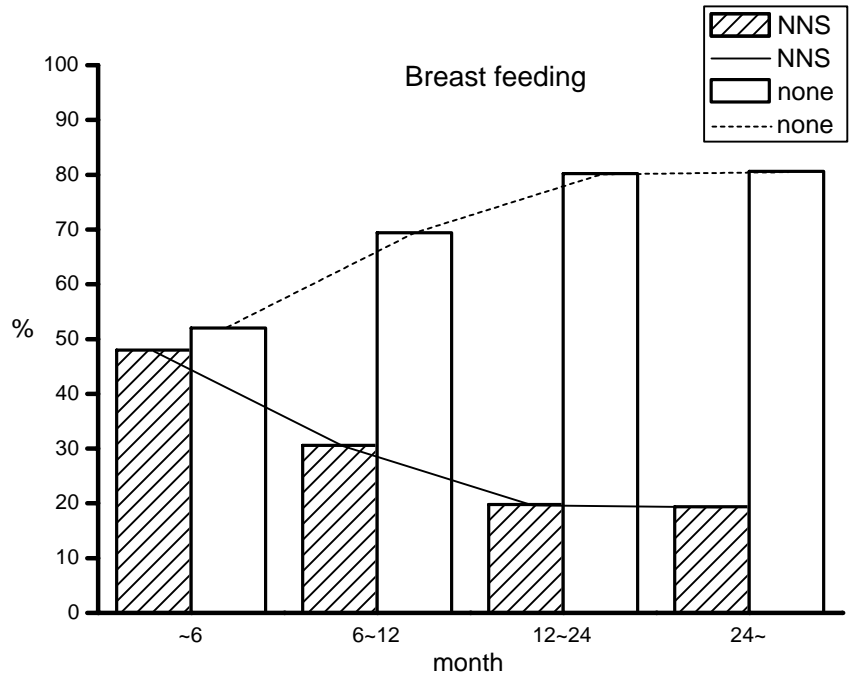

Fig. 1. Correlation of breast feeding duration and non-nutritive sucking. The longer breast feeding, the less non-nutritive sucking (Linear by linear test, $p=0.000$ ).

빨기 습관의 유병률은 유의하게 감소하는 경향을 보였다 $(p<$ 0.001)(Fig. 1). 모유수유 기간에 따른 손가락빨기 및 인공젖 꼭지빨기 각각의 빈도는 Table 4 와 같으며 모유수유 기간이 길 어질수록 손가락빨기 및 인공젖꼭지빨기 둘 다 유의하게 감소 하였다.

젖병사용기간에 따른 비수유성 빨기 습관 유병률의 분석결과 는 젖병을 사용하는 기간이 길어질수록 유병률이 증가되는 경 향을 보였다(Fig. 2). 젖병 사용 여부와 비수유성 빨기 습관 유 병률을 분석한 결과 젖병을 사용하지 않은 아이는 유의하게 낮 은 비율 $(p<0.001)$ 로 비수유성 빨기 습관이 발생되었고, 젖병 을 전혀 사용하지 않은 아이와 사용한 아이의 Odd Ratio는 3.01로 젖병을 사용하여 수유를 하는 경우 모유 수유 어린이보 다 약 3 배의 위험도로 비수유성 빨기 습관이 발생됨을 알 수 있 었다(Fig. 3).

\section{5) 어머니의 직업}

어머니의 직업과 비수유성 빨기 습관의 관계는 비수유성 빨 기 습관을 하는 아이와 하지 않은 아이의 비율 간에 유의한 차 이가 없었다 $(p>0.05)$.

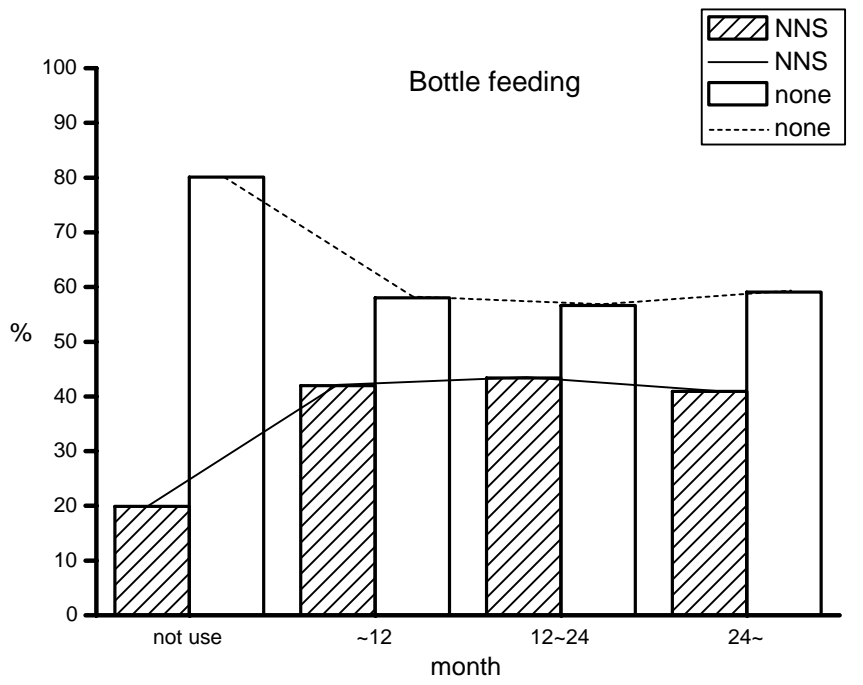

Fig. 2. Correlation of bottle feeding duration and non-nutritive sucking (Linear by linear test, $p=0.000$ ).

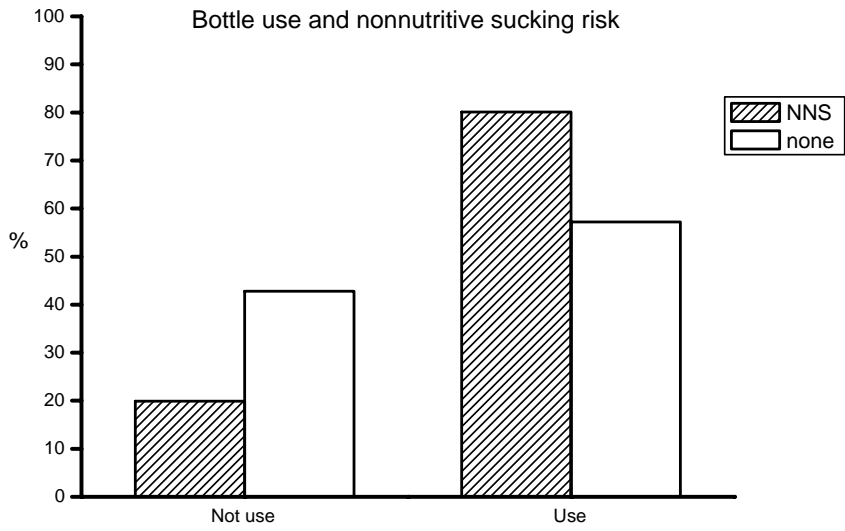

Fig. 3. Bottle use and non-nutritive sucking risk, bottle feeding has about 3 times the risk of non-nutritive sucking compared to absolute breast feeding $(\mathrm{OR}=3.01)$.

Table 4. Breast feeding duration and finger sucking and pacifier sucking prevalence

\begin{tabular}{|c|c|c|c|c|}
\hline & Duration & Finger & Pacifier & $p$-value \\
\hline \multirow{4}{*}{ Breast feeding } & $\sim 6$ month & $79(44.1 \%)$ & $74(76.3 \%)$ & \multirow{4}{*}{$0.000^{*}$} \\
\hline & $6 \sim 12$ month & $45(25.1 \%)$ & $15(15.5 \%)$ & \\
\hline & 12 24 month & $49(27.4 \%)$ & $8(8.2 \%)$ & \\
\hline & $24 \sim$ month & $6(3.4 \%)$ & $0(0.0 \%)$ & \\
\hline
\end{tabular}

Chi-square test, significant at $p<0.05 \operatorname{level}(*)$ 


\section{3. 비수유성 빨기 습관의 유형, 빈도, 기간}

1) 유형

비수유성 빨기 습관을 한다고 답한 276명 중 손가락을 빤다 고 답한 경우가 179 명 $(62.6 \%)$ 으로 인공젖꼭지를 빤다고 답한 97 명 $(37.4 \%)$ 보다 더 많았다.

2) 빈도

손가락빨기를 하는 아이들 중 손가락을 잘 때만 빨았다는 응 답이 $67.3 \%$, 평소에도 자주 빨았다는 응답이 $32.7 \%$ 였고, 인 공젖꼭지는 잘 때만 빨았다는 응답이 $59.8 \%$, 평소에도 자주 빨 았다는 응답이 $40.2 \%$ 로 두 습관 사이에 유의한 차이는 없었다.

\section{3) 기간}

손가락을 6 개월 미만 빨았다는 응답은 $21.3 \%, 12 \sim 24$ 개월 은 $25.7 \%, 24 \sim 36$ 개월은 $15.6 \%, 36$ 개월 이상은 $37.4 \%$ 이 었으며 인공젖꼭지빨기를 한 기간은 6 개월 미만이 $44.3 \%$, 12 24개월이 $43.3 \%, 24 \sim 36$ 개월이 $10.3 \%, 36$ 개월 이상이 $2.1 \%$ 이었다. 24 개월 미만에서는 손가락빨기 보다 인공젖꼭지 빨기 비율이 더 높지만 36 개월 이상에서 손가락빨기의 비율이
더 높은 것으로 보아 손가락빨기는 인공젖꼭지빨기보다 더 오 래 지속되는 경향이 있었다(Table 5).

\section{4. 비수유성 빨기 습관과 유치열 교합과의 관계(Table 6)}

1) 전치부 교합

본 연구에서 수평피개 증가를 보이는 어린이는 86 명이었고 그중 61 명 $(70.9 \%)$ 이 비수유성 빨기 습관이 있는 아이였으며 비수유성 빨기 습관이 있는 아이에서 없는 아이들 보다 수평 피 개 증가를 보일 위험도가 약 6 배 $(\mathrm{OR}=6.086)$ 이었다. 전치부 개방교합을 보인 아이는 17 명이며 그 중 15 명 $(88.2 \%)$ 이 비수 유성 빨기 습관이 있었다고 응답한 어린이로 비수유성 빨기 습 관을 하지 않은 아이에 비해 전치부 개방교합이 발생할 위험은 약 16 배 $(\mathrm{OR}=16.456)$ 이었다.

\section{2) 견치 교합}

본 연구에서 2 급 견치관계를 보이는 어린이 74 명 중 46 명이 비수유성 빨기 습관이 있었다고 응답한 어린이로 비수유성 빨 기 습관이 있는 어린이에서 1 급, 3 급 견치관계와 비교해 유의 한 차이가 있었다 $(p<0.05)$.

Table 5. Correlation of non-nutritive sucking type, frequency and duration

\begin{tabular}{llccc}
\hline & & Finger sucking & Pacifier sucking & $p$ - value \\
\hline Prevalence & & $179(62.6 \%)$ & $97(37.4 \%)$ & $58(59.8 \%)$ \\
Frequency & Only during sleeping & $120(67.3 \%)$ & $39(40.2 \%)$ & 0.473 \\
\hline & Frequently, at any time & $59(32.7 \%)$ & $43(44.3 \%)$ & $42(43.3 \%)$ \\
Duration & $\sim 12$ month & $38(21.3 \%)$ & $10(10.3 \%)$ & $0.000^{*}$ \\
& $12 \sim 24$ month & $46(25.7 \%)$ & $2(2.1 \%)$ & \\
\hline Total & $24 \sim 36$ month & $28(15.6 \%)$ & &
\end{tabular}

Chi-square test, significant at $p<0.05$ level( $*)$

Table 6. Non-nutritive sucking and malocclusion

\begin{tabular}{|c|c|c|c|c|}
\hline & & NNS & None & $p$-value \\
\hline \multirow{4}{*}{ Overjet } & Normal & $180(28.6 \%)$ & $447(71.4 \%)$ & \multirow{4}{*}{$0.000^{*}$} \\
\hline & Excessive & $61(70.9 \%)$ & $25(29.1 \%)$ & \\
\hline & Edge to edge & $11(40.2 \%)$ & $16(59.3 \%)$ & \\
\hline & Ant. crossbite & $11(25.6 \%)$ & $32(74.4 \%)$ & \\
\hline \multirow{4}{*}{ Overbite } & Normal & $206(31.4 \%)$ & $450(68.6 \%)$ & \multirow{4}{*}{$0.000^{*}$} \\
\hline & Openbite & $15(88.2 \%)$ & $2(11.8 \%)$ & \\
\hline & Edge to edge & $10(37.0 \%)$ & $17(63.0 \%)$ & \\
\hline & excessive & $32(38.6 \%)$ & $51(61.4 \%)$ & \\
\hline \multirow{3}{*}{ Canine relation } & Class I & $205(30.7 \%)$ & $463(69.3 \%)$ & CI vs CII $0.000^{*}$ \\
\hline & Class II & $46(62.2 \%)$ & $28(37.8 \%)$ & \multirow{2}{*}{$\begin{array}{l}\text { CI vs CIII } 0.864 \\
\text { CII vs CIII } 0.001^{*}\end{array}$} \\
\hline & Class III & $12(29.3 \%)$ & $29(70.7 \%)$ & \\
\hline \multirow{2}{*}{ Post. crossbite } & Normal & $249(32.3 \%)$ & $515(67.7 \%)$ & \multirow{2}{*}{$0.000^{*}$} \\
\hline & Abnormal & $14(73.7 \%)$ & $5(26.3 \%)$ & \\
\hline Total & & 263 & 520 & $263 / 783$ \\
\hline
\end{tabular}

"Chi-square test, significant at $p<0.05$ level(*) 
3) 구치부 교합

전체 어린이 중 구치부 반대교합이 있는 어린이는 19 명이었 으며 그중 14 명이 비수유성 빨기 습관이 있는 어린이로 비수유 성 빨기 습관이 없는 어린이와 비교 시 유의한 차이가 있었다 $(p$ $<0.05)$. 제 1 유구치 또는 유견치가 맹출 되지 않아서 교합을 확인하기 어려웠던 58 명은 제외되어 총 783 명이 포함되었다.

5. 비수유성 빨기 습관 유형과 유치열 부정교합과의 관계 (Table 7)

수평피개 증가를 보이는 어린이 중 손가락빨기를 한 어린이 는 $27.3 \%$, 전치부 개방교합을 보이는 어린이 중 손가락빨기를 한 어린이는 $7.3 \%, 2$ 급 견치관계를 보이는 어린이 중 손가락빨 기를 한 어린이는 $21.2 \%$, 구치부 반대교합을 보이는 어린이중 손가락빨기를 한 어린이는 $6.1 \%$ 로 각각 $12.4 \%, 2.1 \%$, $8.2 \%, 3.1 \%$ 를 보이는 인공젖꼭지빨기를 한 어린이보다 높은 비율이었고 통계분석 시 구치부 반대교합을 제외하면 모두 유
의한 차이가 있었다. 따라서 손가락빨기가 인공젖꼭지빨기 보 다 수평피개 증가, 전치부개방교합, 2 급 견치관계, 구치부 반대 교합을 일으키는 경향이 크다는 것을 알 수 있었다.

6. 비수유성 빨기 습관의 지속기간과 유치열 교합과의 관계 (Table 8)

비수유성 빨기 습관의 지속기간과 유치열 부정교합 발생과의 관계는 Table 8 과 같다. 대부분의 교합이상은 24 개월 이상 습 관이 지속될 경우 나타났으며 비수유성 빨기 습관의 지속기간 이 길어질수록 교합이상이 유발될 위험성이 커지는 경향을 보 였다 $(p<0.05)$.

7. 비수유성 빨기 습관의 빈도와 유치열 교합과의 관계 (Table 9)

손가락빨기를 한 어린이와 인공젖꼭지빨기를 한 어린이의 습

Table 7. Non-nutritive sucking type and malocclusion

\begin{tabular}{cccc}
\hline & Finger sucking & Pacifier sucking & $p$-value \\
\hline Excessive Overjet & $49 / 179(27.3 \%)$ & $12 / 97(12.4 \%)$ & $0.01^{*}$ \\
Openbite & $13 / 179(7.3 \%)$ & $2 / 97(2.1 \%)$ & $0.032^{*}$ \\
CII canine & $38 / 179(21.2 \%)$ & $8 / 97(8.2 \%)$ & $0.01^{*}$ \\
Posterior crossbite & $11 / 179(6.1 \%)$ & $3 / 97(3.1 \%)$ & 0.415 \\
\hline Total & & & \\
\hline
\end{tabular}

Chi-square test, significant at $p<0.05 \operatorname{level}\left({ }^{*}\right)$

Table 8. Non-nutritive sucking duration and malocclusion

\begin{tabular}{|c|c|c|c|c|c|}
\hline & $\sim 12$ month & 12 24 month & 24 36 month & $36 \sim$ month & $p$-value \\
\hline Excessive overjet & $5(8.2 \%)$ & $16(26.2 \%)$ & $13(21.3 \%)$ & $27(44.3 \%)$ & \multirow{2}{*}{$0.000^{*}$} \\
\hline Normal & $66(36.7 \%)$ & $63(35.0 \%)$ & $26(14.4 \%)$ & $35(19.4 \%)$ & \\
\hline Openbite & $0(0.0 \%)$ & $1(6.6 \%)$ & $2(13.4 \%)$ & $12(80.0 \%)$ & \multirow{2}{*}{$0.000^{*}$} \\
\hline Normal & $66(32.0 \%)$ & $66(32.0 \%)$ & $32(15.5 \%)$ & $42(23.3 \%)$ & \\
\hline CII canine & $4(8.7 \%)$ & $6(13.0 \%)$ & $10(21.7 \%)$ & $26(56.5 \%)$ & CI vs CII $0.000^{*}$ \\
\hline CI canine & $67(32.8 \%)$ & $73(35.8 \%)$ & $27(13.2 \%)$ & $37(18.1 \%)$ & CII vs CIII $0.000^{*}$ \\
\hline CIII canine & $5(41.7 \%)$ & $4(33.3 \%)$ & $1(8.3 \%)$ & $2(16.7 \%)$ & CI vs CIII 0.358 \\
\hline Posterior crossbite & $1(7.1 \%)$ & $2(14.2 \%)$ & $3(21.4 \%)$ & $8(57.1 \%)$ & \multirow{2}{*}{$0.002^{*}$} \\
\hline Normal & $75(30.1 \%)$ & $80(32.1 \%)$ & $36(14.5 \%)$ & $53(21.3 \%)$ & \\
\hline
\end{tabular}

Linear by Linear test, significant at $p<0.05 \operatorname{level}\left({ }^{*}\right)$

Table 9. Non-nutritive sucking frequency and malocclusion

\begin{tabular}{llcccc}
\hline & & Excessive overjet & Openbite & CII canine relation & Posterior crossbite \\
\hline \multirow{2}{*}{ Finger sucking } & Just sleeping & $29 / 12(24.20 \%)$ & $9 / 120(7.50 \%)$ & $23 / 120(19.20 \%)$ & $9 / 120(7.50 \%)$ \\
& Frequently & $20 / 59(33.90 \%)$ & $4 / 59(6.80 \%)$ & $15 / 59(25.40 \%)$ & $2 / 59(3.40 \%)$ \\
\hline$p$ - value & & 0.101 & 0.204 & 0.591 & 0.555 \\
\hline \multirow{2}{*}{ Pacifier sucking } & Just sleeping & $6 / 58(10.30 \%)$ & $1 / 58(1.70 \%)$ & $5 / 58(8.60 \%)$ & $1 / 58(1.70 \%)$ \\
& When needed & $6 / 39(15.40 \%)$ & $1 / 39(2.60 \%)$ & $3 / 39(7.70 \%)$ & $2 / 39(5.10 \%)$ \\
\hline$p$-value & & 0.473 & 0.590 & 0.908 & 0.506 \\
\hline Total & & & $136 / 263$ &
\end{tabular}

Chi square test, Fisher's exact test 
관의 빈도에 따라 나타나는 교합이상 빈도는 Table 9 와 같으며 손가락과 인공젖꼭지 두 가지 모두 잘 때만 빠는 경우와 자주 빨았다고 응답한 경우 교합이상이 유발되는 양상은 비슷하였고 빨기의 빈도와 교합변화에는 유의한 차이가 없었다 $(p>0.05)$.

\section{IV. 총괄 및 고찰}

비수유성 빨기 습관은 정상적인 발달 과정으로서 1 3세 동 안에 자연히 소멸되지만 일부 어린이에서는 이후까지 지속되며 성장하는 어린이의 구강에 비정상적인 힘이 가해져 골격적 부 조화를 유발시킬 수 있어 주의가 필요하달. 이런 문제점 때문 에 북유럽에서는 오래 전부터 비수유성 빨기 습관의 유병률에 대한 연구가 활발하였다 ${ }^{2.5 .12 .14)}$. 이외 미국, 브라질 등 여러 나라 에서도 연구가 진행되었으나 우리나라에서의 연구는 현재까지 발표된 바가 없다.68.21). 북유럽 등 서구와는 문화 관습의 차이가 있으므로 비수유성 빨기 습관의 유병률도 많이 다를 것이라는 가설 하에 본 연구가 계획되었다.

북유럽 국가들에서는 인공젖꼭지빨기가 우세하여 유병률이 70 90\%에 이르나 아시아 지역의 일본이나 홍콩의 연구에서 는 25 35\%의 유병률을 보고하고 있으며 7.9$)$ 이는 아시아 지역 에서 양육 시 모자 관계가 밀착된 것과 관련이 있을 것으로 생 각된다. 아이를 따로 재우는 경우가 많고 안고 달래는 경우가 적은 북유럽 등 서구 여러 나라에서는 보호자가 인공젖꼭지를 물리는 경우가 더 많고 아시아에서는 아이를 안아서 달래는 경 우가 더 많기 때문으로 생각된다. 본 연구에서 인공젖꼭지 사용 빈도는 전체 어린이 중 $10 \%$ 이며 비수유성 빨기 습관이 있는 어린이 중 35\%정도로 비교적 낮았으며 2007년 유 등22)의 연구 에서 보고된 $19.9 \%$ 보다 낮아졌음을 알 수 있었다. 이러한 결과 는 유 등의 연구에서 젖병사용을 한 적이 없다고 답변한 경우가 $7.5 \%$ 였으나 본 연구에서는 $42.4 \%$ 로 젖병사용이 감소한 것과 관련이 있을 것으로 생각된다.

성별에 따른 유병률은 여아에서 우세하다는 연구와 남녀 성 비가 차이가 없다는 연구가 있으나 ${ }^{12-16)}$ 본 연구에서는 여아 $37.7 \%$, 남아에서 $29.0 \%$ 로 남아에 비해 여아가 유의하게 높았 다. 이는 Hanna, Infante 등의 연구결과와 일치 한다 ${ }^{13.23)}$. 이 는 습관이 유전적, 환경적인 영향을 받음을 보여주며 ${ }^{16)}$, 남아의 경우 여아보다 신체활동이 더 많아 빨기 습관의 욕구가 승화되 었을 가능성이 높아 이런 결과가 나왔을 것으로 생각된다.

또한 본 연구에서는 미숙아에서 대략 $50 \%$ 의 유병률을 보여 정상아에 비해 유의하게 높았다. 본 연구의 미숙아 비율은 $6.9 \%$ 였다. 2009년 보건복지부에서 제출한 국정감사자료에 의 하면 미숙아 비율은 $4.88 \%$ 이며 증가 추세라고 하였다. 이는 본 연구의 결과와 비슷하나 본 연구의 경우 미숙아 비율이 약간 많 았다. 이유는 소아전문치과에 내원한 아이만 대상이었으므로 미숙아나 저체중아로 건강에 더 주의가 필요한 아이들은 일반 치과보다는 소아치과로 직접 내원하거나, 의뢰되었을 확률이 높아서 미숙아의 비율이 약간 높았을 것으로 생각된다. 미숙아 에서 비수유성 빨기 습관의 유병률이 높았던 것은 미숙아에서
비수유성 빨기 습관이 full oral feeding을 할 수 있을 때까지의 기간을 줄이고 병원 입원기간을 줄인다는 보고가 있어 미숙아 에서의 인공젖꼭지의 사용이 장려된 것과 관련 있을 것으로 생 각 된다 ${ }^{24,25)}$.

본 연구에서 출생순서는 유의한 차이가 없었으나 Warren 등1ㅣ 은 비수유성 빨기 습관을 36 개월 이상 지속한 아이는 외동인 경우가 많았다고 하였으며 Jahanbin 등히은 형제가 여럿인 어 린이는 인공젖꼭지를 적게 사용하는 경향을 보였으나 손가락빨 기는 유의한 차이가 없었다고 하였다. 본 연구에서 출생순서는 유의한 차이가 없었으며 본 연구에서 많은 어린이가 손가락빨 기를 하였으므로 Jahanbin 등의 연구와 맥락을 같이 한다고 할 수 있다.

모유수유 기간이 짧은 것이 손가락빨기 및 인공젖꼭지 사용 같은 비수유성 빨기 습관 유병률의 증가에 직접적인 영향을 준 다는 것은 여러 논문에서 보고되어왔다 2.11.15.27.28). 인공젖꼭지를 자주 사용하는 아이는 모유수유를 하는 시간이 적어진다는 연 구도 있다. 하지만 모유수유를 오래 한 아이들에서 더 높은 비 율로 손가락빨기를 한다는 연구도 있고, 모유수유 기간이 길면 인공젖꼭지 사용도 증가하고 손가락빨기는 오히려 줄어든다는 연구도 있어 수유와 비수유성 빨기 습관의 관계는 더 많은 연구 가 필요할 것으로 생각 된다 $16,28,29)$. 본 연구에서는 모유수유의 기간이 길어질수록 손가락빨기, 인공젖꼭지빨기 모두 유의하게 감소하였다.

젖병사용 기간에 대한 조사에서 젖병사용이란 수유를 젖병으 로 한 경우로 한정하여 보호자들에게 설명하였고 모유수유하면 서 쥬스나 물 등을 젖병으로 준 경우도 있을 수 있으나 본 연구 에는 포함시키지 않았다. 또한 모유를 젖병에 담아준 경우는 젖 병사용으로 분류하였으며 모유와 젖병을 혼합해서 사용한 경우 도 있을 수 있다고 생각되나 설문에 답한 보호자들도 이에 대해 서는 명확하게 구분해서 기억하지 못했으며 모호한 답변을 했 을 수 있을 것으로 생각되었다. 이러한 점이 결과에 영향을 줄 수 있을 것으로 생각되어 젖병사용에 있어서만 use (사용한 적 이 있다) 와 not use (전혀 사용한 적이 없다) 항목을 추가로 분석하였고 결과는 젖병의 사용여부는 비수유성빨기습관과 연 관될 가능성이 3배 높은 것으로(odd ratio 3.01) 나타났다.

손가락빨기는 인공젖꼭지빨기와 비교하여 습관의 지속기간이 유의하게 길었으며 이는 다른 연구들의 결과와 일치 한다.,26). 습관 중단의 측면에서 보자면 손가락빨기보다 인공젖꼭지를 사 용하도록 하는 것이 유리하다고 볼 수 있다.

대개 만 3 4세 까지의 비수유성 빨기 습관은 정상으로 여겨 졌으나 최근 여러 연구자들은 2 세 이후에는 인공젖꼭지의 사용 을 중단하는 것이 구치부 반대교합의 위험성을 줄일 수 있다고 하였다 ${ }^{11.15,30)}$. Ogaard 등 ${ }^{311}$ 은 인공젖꼭지를 2 년 이상 사용한 경 우 상악의 폭이 작아지며, 3년 이상 사용 시 하악폭이 증가하였 음을 보고했다. 본 연구에서도 습관의 지속기간이 길어질수록 수평피개의 증가, 전치부 개방교합, 2 급견치관계, 구치부 반대 교합 모두 증가되는 경향을 보였으나 이 결과만으로 습관의 중 단을 권고할 시기를 결정하기는 어려우며 습관의 지속기간과 
교합의 관계에 대해서는 좀 더 많은 연구가 필요할 것으로 생각 된다.

비수유성 빨기 습관이 부정교합을 유발하는 심도는 기간, 강 도, 빈도에 좌우된다고 알려져 있다. 하지만 본 연구에서 비수 유성 빨기 습관을 자주 한 경우와 잘 때만 하였다고 응답한 경 우 유치열 교합변화에 유의한 차이가 관찰되지 않았다. 이것은 본 설문의 특성상 습관의 심도에 대한 평가가 보호자의 주관적 인 판단에 의한 것으로 하루 평균 빠는 시간과 같은 객관적인 기준을 제시한 차후의 연구가 좀 더 필요할 것으로 생각된다.

습관의 종류에 대한 분석에서는 손가락빨기가 인공젖꼭지빨 기습관보다 유치열 교합에 더 큰 영향을 주는 결과를 보였으며 보다 이른 시기에 손가락을 빠는 습관의 중단을 권고할 필요가 있음을 보여준다.

본 연구는 18 65개월 사이의 어린이를 대상으로 하였으며 연령층의 폭이 넓어 나이별 유병률을 결정하기에는 특정연령의 표본수가 작았다. 연령별로 습관의 유병률을 결정하기 위해서 는 각 연령별로 집중적인 조사를 하는 심화연구가 필요할 것으 로 생각된다. 또한 본 연구에서는 유치열의 교합이 완성되지 않 은 연령의 어린이부터 포함되어 아직 충분히 교합변화가 나타 나지 않은 상태일 수 있으며 그로인해 부정교합을 보인 어린이 의 수가 부정확하게 조사되었을 가능성이 있다. 유치열의 교합 이 완성되고 비수유성 빨기 습관의 영향이 충분히 나타나는 5 6세 이후에 후향적으로 비수유성 빨기습관의 여부, 지속기 간, 빈도를 조사하고 유치열의 교합과의 연관성을 평가하는 추 가적인 연구가 필요할 것으로 생각된다.

\section{V. 결 론}

구강검진을 위해 대전지역 소아치과에 내원한 18 개월에서 65 개월 사이의 어린이와 보호자 841 명을 대상으로 설문과 교합 검사를 시행하고 이를 분석한 결과 다음과 같은 결론을 얻었다.

비수유성 빨기 습관의 유병률은 $32.8 \%$ 였으며, 손가락빨기가 인공젖꼭지빨기보다 더 높은 빈도를 보였다 $(p<0.05)$. 여아에 서 남아보다 비수유성 빨기 습관의 유병률이 더 높았으며 $(p<$ $0.05)$ 비수유성 빨기 습관의 유병률과 출생순서 및 엄마의 직 업유무는 관련이 없었다 $(p>0.05)$. 모유수유의 기간이 길어질 수록 비수유성 빨기 습관의 발생률은 감소되는 경향을 보였으 며 $(p<0.05)$ 이러한 습관의 지속기간이 길어질수록 더 높은 빈도로 전치부 개방교합, 수평피개의 증가, 2 급 견치관계, 구치 부 반대교합이 나타났다 $(p<0.05)$. 인공젖꼭지빨기보다 손가 락빨기에 의한 교합변화가 더 높은 빈도로 관찰되었다 $(p<$ 0.05).

\section{References}

1. Johnson ED, Larson BE : Thumb-sucking: literature review. ASDC J Dent Child, 60:385-391, 1993.

2. Larsson EF, Dahlin KG: The prevalence and the etiology of the initial dummy- and finger- sucking habit. Am J Orthod, 87:432-435, 1985.

3. Graber TM : Thumb and finger sucking. Am $J$ Orthod, 45:259-264, 1959.

4. Korean academy of pediatric dentistry : Pediatric dentistry, 4th ed. Shinhung International, Inc, Seoul, p428-456, 2007.

5. Ravin JJ : The prevalence of dummy and finger sucking habits in Copenhagen children until the age of 3 years. Community Dent Oral Epidemiol, 2:316322, 1974.

6. Bishara SE, Warren JJ, Broffitt B, Levy SM : Changes in the prevalence of nonnutritive sucking patterns in the first 8 years of life. Am $J$ Orthd Dentofacial Orthop, 130: 31-36, 2006.

7. Yonezu T, Yakushiji M : Longitudinal study of influence of prolonged non-nutritive sucking habits on dental caries in japanese children from 1.5 3 years of age. Bull Tokyo Dent Coll, 49:59-63, 2008.

8. Nelson EA, Yu LM, Williams S : International child care practice study: Breast feeding and pacifier use. J Hum Lact, 21:289-294, 2005.

9. Chan SC, Tsai JS, King NM : Feeding and oral hygiene habits of preschool children in Hongkong and their caregivers dental knowledge and attitudes. Int J Pediatr Dent, 12:322-331, 2002.

10. Telles FB, Ferreira RI, Magalhães Ldo N, ScavoneJunior $\mathrm{H}$ : Effect of breast- and bottle-feeding duration on the age of pacifier use persistence. Braz Oral Res, 23:432-438, 2009.

11. Scavone-Jr H, Guimarães-Jr CH, Vellini-Ferreira F : Association between breastfeeding duration and non-nutritive sucking habits. Community Dent Health, 25:161-165, 2008.

12. Larsson E, Ogaard B, Lindsten R : Dummy- and finger-sucking habits in young Swedish and Norwegian children. Scand J Dent Res, 100:292295, 1992.

13. Hanna JC : Breast feeding versus bottle feeding in relation to oral habits. $J$ Dent Child, 34:243-249, 1967.

14. Larsson E : Dummy and finger sucking habits with special attention to their significance for facial growth and occlusion. Sven Tandlak Tidskr, 68:5559, 1975.

15. Adair SM : Pacifier use in children: a review of recent literature. Pediatr Dent, 25:449-458, 2003.

16. Paunio P, Rautava P, Sillanpää M : The finish fami- 
ly competence study: the effects of living conditions on sucking habits in 3-year-old finish children and association between these habits and dental occlusion. Acta Odontol Scand, 51:23-29, 1993.

17. Ngom PI, Diagne F, Hennequin M, et al. : Prevalence and factors associated with non-nutritive sucking behavior. Cross sectional study among 5- to 6-year-old Senegalese children. Orthod Fr, 79:99106, 2008

18. Warren JJ, Levy SM, Nowak AJ, Tang S : Non nutritive sucking behaviors in preschool children: a longitudinal study. Pediatr Dent, 22:187-191, 2000.

19. Melink S, Vagner MV, Hocevar-Boltezar I, Ovsenik M : Posterior crossbite in the deciduous dentition period, its relation with sucking habits, irregular orofacial functions, and otolaryngological findings. Am J Orthod Dentofacial Orthop, 138:32-40, 2010.

20. Karjalainen S, Rönning O, Lapinleimu H, Simell O : Association between early weaning, non-nutritive sucking habits and occlusal anomalies in 3-year-old Finnish children. Int $J$ Paediatr Dent, 9:169-173, 1999.

21. Katz CR, Rosenblatt A, Gondim PP : Nonnutritive sucking habits in Brazilian children: effects on deciduous dentition and relationship with facial morphology. Am J Orthod Dentofacial Orthop, 126:5357, 2004

22. You RK, Lee KH, Ra JY, Lee DJ : Prevalence of severe early childhood caries and feeding practices in preschool children in Iksan city. J Korean Acad Pediatr Dent, 34:383-389, 2007.

23. Infante $\mathrm{PF}$ : An epidemioloigic study of finger habits in preschool children, as related to malocclusion, socioeconomic status, race, sex and size of community, ASDC J Dent Child, 43:33-38, 1976.
24. Bingham PM, Ashikaga T, Abbasi S : Prospective study of non-nutritive sucking and feeding skills in premature infants. Arch Dis Child Fetal Neonatal Ed, 95:194-200, 2010.

25. Pinelli J, Symington A : Non-nutritive sucking for promoting physiologic stability and nutrition in preterm infants. Cochrane Database Syst Rev, 19: CD001071, 2005.

26. Jahanbin A, Mokhber N, Jabbarimani A : Association between sociodemographic factors and nutritive and non-nutritive sucking habits among Iranian girls. Eastern Mediterr Health J, 16:11431172, 2010.

27. Aarts C, Hörnell A, Gebre-Medhin $\mathrm{M}$ et al. : Breastfeeding patterns in relation to thumb sucking and pacifier use. Pediatrics, 104:e50, 1999.

28. Moimaz SA, Zina LG, Saliba NA, Saliba O : Association between breast-feeding practices and sucking habits: a cross-sectional study of children in their first year of life. J Indian Soc Pedod Prev Dent, 26:102-106, 2008

29. Vaidakas G, Oulis C, Berdouses E : Profile of nonnutritive sucking habits in relation to nursing behavior in pre-school children. $J$ Clin Pediatr Dent, 22:133-136, 1998

30. Góis EG, Ribeiro-Júnior HC, Pordeus IA, et al. : Influence of nonnutritive sucking habits, breathing pattern and adenoid size on the development of malocclusion. Angle Orthod, 78:647-654, 2008.

31. Ogaard B, Larsson E, Lindsten R : The effect of sucking habits, cohort, sex, intercanine arch widths, and breast or bottle feeding on posterior crossbite in Norwegian and Swedish 3-year-old children. Am J Orthod Dentofacial Orthop, 106:161-166, 1994. 
국문초록

\title{
대전지역 미취학 어린이의 비수유성 빨기 습관에 대한 조사 연구
}

\author{
박승효 ${ }^{1} \cdot$ 이난영 ${ }^{1} \cdot$ 이상호 $^{1} \cdot$ 정혜란 $^{2}$ \\ ${ }^{1}$ 조선대학교치의학전문대학원 소아치과학교실, ${ }^{2}$ 동아인재대학교 치위생과
}

이 연구의 목적은 대전지역 미취학 어린이의 비수유성 빨기 습관의 유병률을 조사하고 이 유병률에 영향을 미치는 기여요 인과의 관련성을 평가하며 비수유성 빨기 습관이 유치열의 교합에 어떤 영향을 주는지 알아보고자 하는 것이다.

구강검진을 위해 개인치과에 내원한 만 18 개월에서 65 개월 사이의 어린이 841 명을 검사하고 그 보호자를 대상으로 설문 조사를 시행하였다.

전체 설문에 대답한 어린이 중 $32.8 \%$ 에서 비수유성 빨기 습관이 있었으며 여아에서 $37.7 \%$ 로 남아보다 유의하게 더 높았 다. 모유 수유의 기간이 길어짐에 따라 비수유성 빨기 습관 유병률은 유의한 감소를 보였으며 출생순서와 엄마의 직업유무는 관련성이 없었다.

손가락빨기가 전체 비수유성 빨기 습관 어린이 중 $62.6 \%$ 로 인공젖꼭지빨기(37.4\%)에 비해 더 우세하였고 습관의 지속기 간 또한 유의하게 길었다. 비수유성 빨기 습관의 지속기간이 길어질수록 유치열 교합이상이 더 많이 관찰되었다.

주요어: 비수유성 빨기 습관, 손가락빨기, 인공젖꼭지빨기, 전치부 개방교합, 수평피개 증가 